\title{
Transcriptional and Posttranscriptional Regulation of Macrophage-specific Colony Stimulating Factor Gene Expression by Tumor Necrosis Factor
}

\author{
Involvement of Arachidonic Acid Metabolites
}

\author{
Matthew L. Sherman, Barbara L. Weber, Rakesh Datta, and Donald W. Kufe \\ Laboratory of Clinical Pharmacology, Dana-Farber Cancer Institute and Harvard Medical School, Boston, Massachusetts 02115
}

\begin{abstract}
The effects of tumor necrosis factor (TNF) on the regulation of macrophage-specific colony stimulating factor (CSF-1) gene expression have been studied in HL-60 cells during monocytic differentiation. CSF-1 transcripts were undetectable in uninduced HL-60 cells, reached maximal levels by $3 \mathrm{~h}$ of exposure to TNF, and returned to that of control cells by $24 \mathrm{~h}$. Transcriptional run-on analysis demonstrated that exposure to TNF stimulated the rate of CSF-1 gene transcription by 6.4fold. The combination of a protein synthesis inhibitor, cycloheximide, and TNF increased levels of CSF-1 mRNA compared with treatment by TNF alone. We also studied the signal transduction mechanisms responsible for regulating TNF-induced CSF-1 mRNA levels. Both 4-bromophenacyl bromide and quinacrine, inhibitors of phospholipase $A_{2}$ activity, blocked TNF-induced increases in CSF-1 transcripts in a concentration-dependent manner, while caffeic acid and nordihydroguaiaretic acid, inhibitors of the 5-lipoxygenase pathway, had no detectable effect on induction of CSF-1 RNA. PGE 2 or dibutyryl cAMP treatment of HL-60 cells in the presence of TNF blocked the expression of CSF-1 mRNA in a dose-dependent manner. These findings suggest that the increase in CSF-1 RNA observed during TNF treatment is regulated, at least in part, by both transcriptional and posttranscriptional mechanisms, and that $\mathbf{P G E}_{2}$ and cAMP regulate transcriptional activation of the CSF-1 gene by TNF. (J. Clin. Invest. 1990. 85:442-447.) colony stimulating factors - cycloheximide • phospholipase $A_{2} \bullet$ prostaglandin $E_{2} \bullet$ cyclic AMP
\end{abstract}

\section{Introduction}

The macrophage-specific colony stimulating factor (CSF-1, also referred to as M-CSF) ${ }^{1}$ stimulates hematopoietic stem cells to form colonies containing monocytes and macrophages $(1,2)$. Semipurified CSF-1 from mouse L929 cell-conditioned media also regulates mouse macrophage production of bio-

Address reprint requests to Dr. M. L. Sherman, Dana-Farber Cancer Institute, 44 Binney Street, Boston, MA 02115.

Received for publication 19 June 1989 and in revised form 18 September 1989.

1. Abbreviations used in this paper: $\mathrm{BPB}, 4$-bromophenacyl bromide; $\mathrm{Bt}_{2} \mathrm{CAMP}$, dibutyryl cAMP; CSF-1, macrophage-specific colony stimulating factor; 5-LO and 15-LO, 5- and 15-lipoxygenase, respectively; NDGA, nordihydroguaiaretic acid; TNF, tumor necrosis factor.

J. Clin. Invest.

(C) The American Society for Clinical Investigation, Inc. $0021-9738 / 90 / 02 / 0442 / 06 \$ 2.00$

Volume 85, February 1990, 442-447 logic factors such as prostaglandin E (3), plasminogen activator (4), interleukin 1 (5), and granulocyte-specific CSF (6). Furthermore, mouse CSF-1 enhances the induction of interferon by lipopolysaccharide or polyinosinic/polycytidylic acid (7), whereas human CSF-1 purified from the pancreatic carcinoma cell line MIA-PaCa stimulates the production of interferon, myeloid colony stimulating activity and tumor necrosis factor (TNF) (8).

In contrast to the known multiple effects of CSF-1 protein, the regulation of CSF-1 gene expression by biologic mediators has not been extensively examined. Phorbol esters and the granulocyte/CSF-1 have been shown to induce CSF-1 expression in MIA-PaCa cells, normal human monocytes, and during monocytic differentiation of human promyelocytic leukemia cells (9-12). Furthermore, recent studies demonstrate that the CSF-1 gene is constitutively expressed in a variety of human ovarian, breast, and lung carcinoma cell lines (13).

TNF is a regulatory cytokine which binds to a specific, high-affinity plasma-membrane receptor. Initially, in vitro studies demonstrated that TNF is cytotoxic or cytostatic to a variety of human and murine tumor cells but has no antiproliferative effects against normal cells. TNF also has pleiotropic effects on hematopoietic cell growth and differentiation. TNF inhibits colony growth of BFU-E, CFU-GM, and CFUGEMM (14-16). TNF also induces monocytic differentiation of HL-60 cells (17) and is associated with rapid down-regulation of c-myc proto-oncogene expression at the transcriptional level $(18,19)$. Recent studies have demonstrated that both transcriptional and posttranscriptional mechanisms regulate granulocyte-specific CSF and granulocyte/CSF-1 expression by TNF in fibroblasts (20). Furthermore, TNF has been shown to induce secretion of CSF-1 by human monocytes (21).

In the present study, we examined the effects of TNF on the regulation of gene expression of CSF-1 in HL-60 cells during monocytic differentiation. Our data show that TNF transcriptionally regulates CSF-1 expression and that CSF-1 transcripts are degraded posttranscriptionally by a labile protein. Furthermore, the induction of CSF-1 by TNF is inhibited by the cyclooxygenase metabolite $\mathrm{PGE}_{2}$, as well as cAMP.

\section{Methods}

Cell culture. The HL-60 promyelocytic cells were grown in RPMI 1640 media containing $15 \%$ FBS supplemented with $100 \mathrm{U} / \mathrm{ml}$ penicillin, $100 \mu \mathrm{g} / \mathrm{ml}$ streptomycin, $2 \mathrm{mM}$ L-glutamine, $1 \mathrm{mM}$ sodium pyruvate, and $1 \mathrm{mM}$ nonessential amino acids. Cell cultures were maintained in a humidified $5 \% \mathrm{CO}_{2}$ in air atmosphere at $37^{\circ} \mathrm{C}$. Human recombinant TNF (Asahi Chemical Industry Co., New York) had a specific activity of $2.3 \times 10^{6} \mathrm{U} / \mathrm{mg}$ and contained $<10 \mathrm{pg}$ endotoxin $/ \mathrm{mg}$ protein by the Limulus lysate assay.

Preparation of RNA and Northern blot hybridization. Total cellular RNA was isolated by the guanidine isothiocyanate-cesium chloride technique as described (22). Total cellular RNA $(20 \mu \mathrm{g})$ was subjected 
to electrophoresis in a $1 \%$ agarose $/ 2.2 \mathrm{M}$ formaldehyde gel, transferred to nitrocellulose paper, and hybridized to one of the following ${ }^{32} \mathrm{P}$-labeled DNA probes: $(a)$ the $0.57-\mathrm{kb}$ Acc I/Eco RI fragment of a human CSF-1 CDNA purified from the pc-CSF-12 plasmid (23); (b) the 4.0-kb Eco RI fragment of the human c-fms gene purified from the pc-fms 102 plasmid (24); and (c) the pAl plasmid containing a 2.0-kb Pst I insert of the chicken beta-actin gene (25).

Hybridization reactions were carried out for $16-24 \mathrm{~h}$ at $42^{\circ} \mathrm{C}$ in $50 \%$ (vol/vol) formamide, $2 \times$ SSC (SSC: $0.15 \mathrm{M}$ sodium chloride, $0.015 \mathrm{M}$ sodium citrate), $1 \times$ Denhardt's solution, $0.1 \%$ (wt/vol) SDS and $200 \mu \mathrm{g} / \mathrm{ml}$ salmon sperm DNA. Filters were washed and exposed to Kodak X-Omat XAR film using an intensifying screen. The autoradiograms were scanned using a laser densitometer (UltroScan XL; LKB Instruments, Inc., Gaithersburg, MD) and analyzed using the Gelscan XL software package (LKB Instruments, Inc.). The intensity of CSF-1 or c-fms hybridization was normalized against beta-actin expression.

Run-on transcriptional analyses. HL-60 cells $\left(10^{8}\right.$ cells per treatment) were washed with ice-cold PBS and the nuclei isolated by lysis in $0.5 \% \mathrm{NP}-40$ buffer as described (22). Nuclei were resuspended in glycerol buffer and incubated in an equal volume of reaction buffer containing $100 \mathrm{mM} \mathrm{KCl}, 0.5 \mathrm{mM}$ each of ATP, GTP, and CTP, and 200 $\mu \mathrm{Ci}$ [alpha- ${ }^{32} \mathrm{P}$ ]UTP $(800 \mathrm{Ci} / \mathrm{mmol}$; New England Nuclear, Boston, MA) at $26^{\circ} \mathrm{C}$ for $30 \mathrm{~min}$. The reaction was terminated by the addition of $100 \mu$ l of $10 \mathrm{mM}$ Tris- $\mathrm{HCl}$ (pH 8.0), $1 \mathrm{mM}$ EDTA, $100 \mathrm{mM} \mathrm{NaCl}$, $20 \mathrm{mM} \mathrm{MgCl}, 150 \mathrm{U} / \mathrm{ml} \mathrm{RNasin}$, and $40 \mu \mathrm{g} / \mathrm{ml} \mathrm{DNase}$ and allowed to incubate at $28^{\circ} \mathrm{C}$ for $15 \mathrm{~min}$. After proteinase $\mathrm{K}$ digestion, the RNA was extracted with phenol/chloroform/isoamyl alcohol (25:24:1) and precipitated in ethanol and $2.5 \mathrm{M}$ ammonium acetate. The RNA was further purified by Sephadex G-50 column separation.

Plasmid DNAs containing various cloned inserts were digested with restriction endonucleases as follows: $(a)$ the 2.0 -kb Pst I fragment of the chicken beta-actin pA1 plasmid; and (b) the 1.6-kb Sal I/Eco RI fragment of the pc-CSF-12 plasmid. The digested DNA was run in a $1 \%$ agarose gel and transferred to nitrocellulose filters by the method of Southern. The filters were prehybridized in $5 \times$ Denhardt's solution, $40 \%$ formamide, $4 \times$ SSC, $5 \mathrm{mM}$ EDTA, $0.4 \%$ SDS, and $100 \mu \mathrm{g} / \mathrm{ml}$ yeast tRNA for $2 \mathrm{~h}$. Hybridization was performed with $10^{7} \mathrm{cpm}$ of ${ }^{32} \mathrm{P}$-labeled RNA/ml hybridization buffer for $72 \mathrm{~h}$ at $42^{\circ} \mathrm{C}$. The filters were then washed in $2 \times \mathrm{SSC}$ and $0.1 \%$ SDS at $37^{\circ} \mathrm{C}$ for $30 \mathrm{~min}, 10$ $\mu \mathrm{g} / \mathrm{ml}$ RNase $\mathrm{A}$ in $2 \times \mathrm{SSC}$ at $37^{\circ} \mathrm{C}$ for $30 \mathrm{~min}$, and $0.1 \times \mathrm{SSC}$ and $0.1 \%$ SDS at $42^{\circ} \mathrm{C}$ for $30 \mathrm{~min}$. Autoradiography was performed for 3-10 d.

\section{Results}

CSF-1 transcripts are rapidly and transiently induced by TNF. We first determined the effects of TNF on the expression of CSF-1 gene transcripts during induction of monocytic differentiation. Northern blot analysis of HL-60 cellular RNA using a CSF-1 cDNA probe is shown in Fig. 1. The level of CSF-1 transcripts increased 20 -fold after $3 \mathrm{~h}$ of exposure to TNF (Fig. $1 A$ ). This increase was transient and the level of CSF-1 transcripts returned to that of control cells by $24 \mathrm{~h}$ (Fig. $1 B$ ). TNF treatment was also associated with the appearance of c-fms transcripts that code for the CSF-1 receptor. However, in contrast to the induction of CSF-1 gene expression, maximal c-fms mRNA levels were detected at $48 \mathrm{~h}$ of TNF treatment (Fig. $1 B$ ). TNF had no effect on levels of actin transcripts.

CSF-1 expression is controlled at both the transcriptional and posttranscriptional levels. Run-on transcriptional assays in isolated nuclei were performed to determine the mechanisms responsible for the regulation of CSF-1 gene expression by TNF. A low level of CSF-1 gene transcription was detectable in untreated HL-60 cells (Fig. 2). In contrast, exposure to TNF
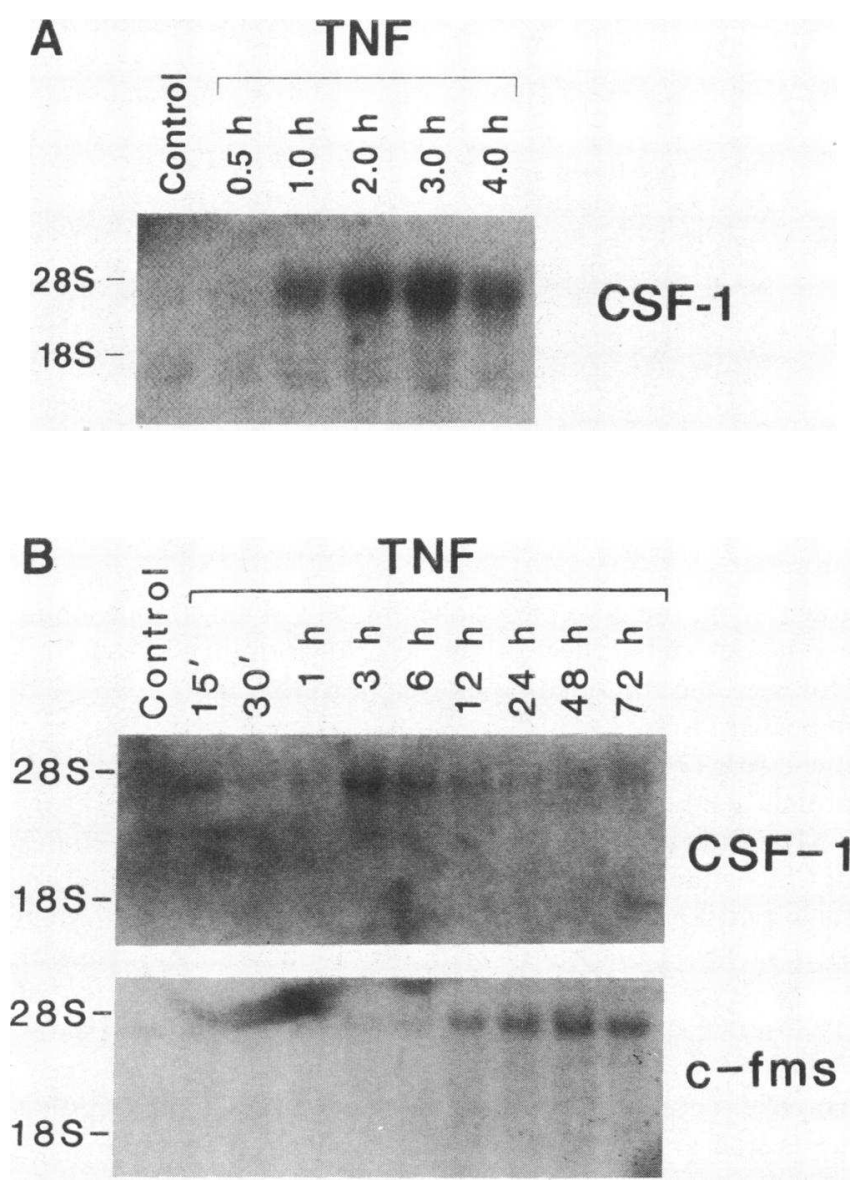

Figure 1. Effects of TNF on CSF-1 and c-fms mRNA levels in HL-60 cells. Northern blot analysis of RNA levels was performed in HL-60 cells after treatment with TNF $(200 \mathrm{U} / \mathrm{ml})$. $(A)$ Total cellular RNA (20 $\mu \mathrm{g} / \mathrm{lane}$ ) was hybridized to a $0.57-\mathrm{kb}{ }^{32}$ P-labeled CSF-1 DNA probe. $(B)$ Hybridization was performed using ${ }^{32} \mathrm{P}$-labeled CSF-1 and c-fms DNA probes. The control lane represents RNA from untreated HL- 60 cells.

for 1 and $2 \mathrm{~h}$ increased CSF-1 gene transcription by 4.0 - and 6.4-fold, respectively (Fig. 2).

Increased levels of CSF-1 mRNA in HL-60 cells exposed to TNF could also result from enhanced stabilization of the CSF-1 transcript. In order to study posttranscriptional regulation of CSF-1 RNA, HL-60 cells were treated with TNF in the

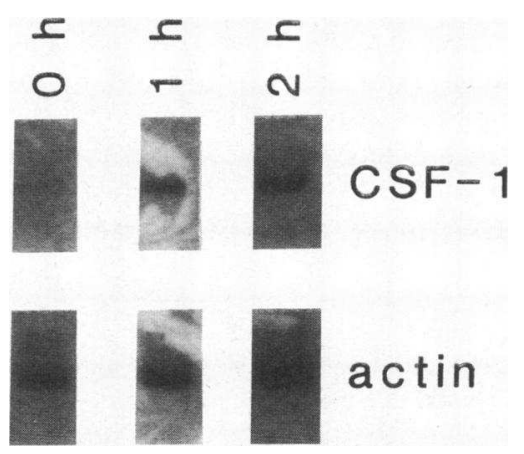

Figure 2. Effects of TNF on rates of CSF-1 gene transcription. HL-60 cell nuclei were isolated at the indicated times as described in Methods. Newly elongated ${ }^{32}$ P-labeled RNA transcripts were hybridized to $2 \mu \mathrm{g}$ CSF-1 or beta-actin DNA insert after restriction enzyme digestion and Southern blotting. 


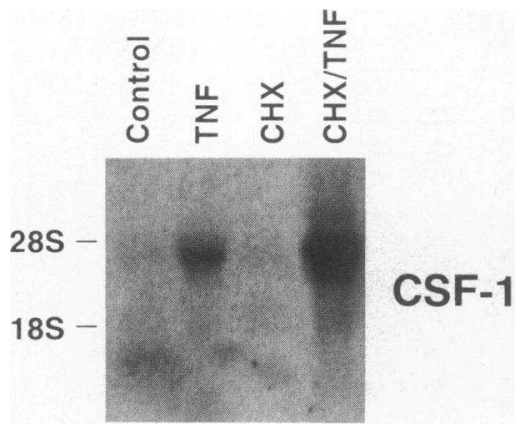

CSF-1 probe. The control lane represents RNA from untreated HL-60 cells.

absence and presence of cycloheximide. Cycloheximide alone had no detectable effect on the accumulation of CSF-1 RNA. However, the combination of cycloheximide and TNF for $3 \mathrm{~h}$ increased levels of CSF-1 by 3.4-fold as compared with treatment with TNF alone (Fig. 3). These results also indicated that protein synthesis is not required for the induction of CSF-1 by TNF. Furthermore, cycloheximide had no effect on the rates of CSF-1 transcription as monitored by nuclear run-on assays (data not shown). These results suggested that cycloheximide affects CSF-1 expression by a posttranscriptional mechanism.

In order to study the posttranscriptional regulation of TNF-induced CSF-1 mRNA levels, HL-60 cells were treated with TNF for $3 \mathrm{~h}$ to induce CSF-1 expression and then exposed to actinomycin-D for various times to inhibit further transcription. The half-life of CSF-1 mRNA as determined by densitometric scanning was $97 \mathrm{~min}$ (Fig. 4). In contrast, inhibition of protein synthesis with cycloheximide in the absence of transcription increased the half-life of CSF-1 mRNA in TNFtreated HL-60 cells to 220 min (Fig. 4). Taken together, these findings suggested that the increase in CSF-1 RNA observed during TNF treatment is also mediated, at least in part, by posttranscriptional mechanisms involving the synthesis of a labile protein that affects the turnover of CSF-1 RNA.

CSF-1 expression is blocked by inhibitors of the arachidonic acid cascade. Recent work in our laboratory has demonstrated that the autoinduction of TNF mRNA by TNF protein in HL-60 cells is associated with increased phospholipase $A_{2}$ activity and arachidonic acid release. ${ }^{2}$ In order to determine whether arachidonic acid metabolism is also involved in CSF-1 expression, we studied the signal transduction mechanisms responsible for regulating TNF-induced CSF-1 transcripts. The induction of CSF-1 RNA by TNF was examined after treatment of HL-60 cells with 4-bromophenacyl bromide (BPB) and quinacrine, inhibitors of phospholipase $A_{2}$, and eicosanoid production $(26,27)$. Both $B P B$ and quinacrine inhibited TNF-induced increases in CSF-1 transcripts in a concentration-dependent manner. For example, $1 \mu \mathrm{M}$ BPB inhibited TNF-induced increases in CSF-1 transcripts by $57 \%$, whereas 5 and $10 \mu \mathrm{M}$ BPB completely blocked this induction (Fig. $5 \mathrm{~A}$ ). Similarly, 2 and $5 \mu \mathrm{M}$ quinacrine inhibited the induction of CSF-1 mRNA by 38 and $64 \%$, respectively,

2. Spriggs, D. R., M. L. Sherman, K. Imamura, M. Mohri, C. Rodriquez, G. Robbins, and D. W. Kufe, manuscript submitted for publication.

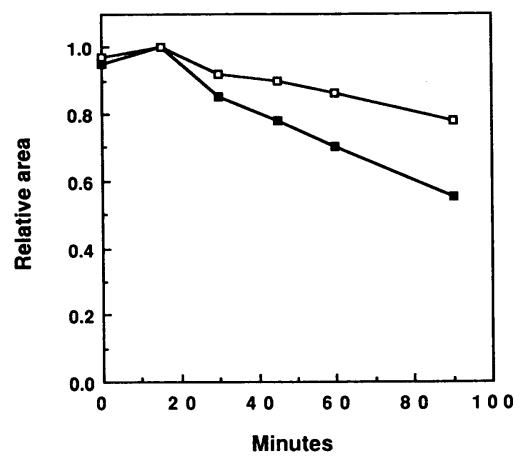

Figure 4. Effects of cy cloheximide on CSF-1 mRNA half-life in TNF-treated HL-60 cells. HL-60 cells were treated with TNF $(200$ $\mathrm{U} / \mathrm{ml}$ ) for $3 \mathrm{~h}$ followed by $5 \mu \mathrm{g} / \mathrm{ml}$ actinomycin-D (๘) or actinomycin-D and cycloheximide ( $\square$ ). Cells were harvested at the indicated times (after the addition of actinomycin-D) and analyzed as described.
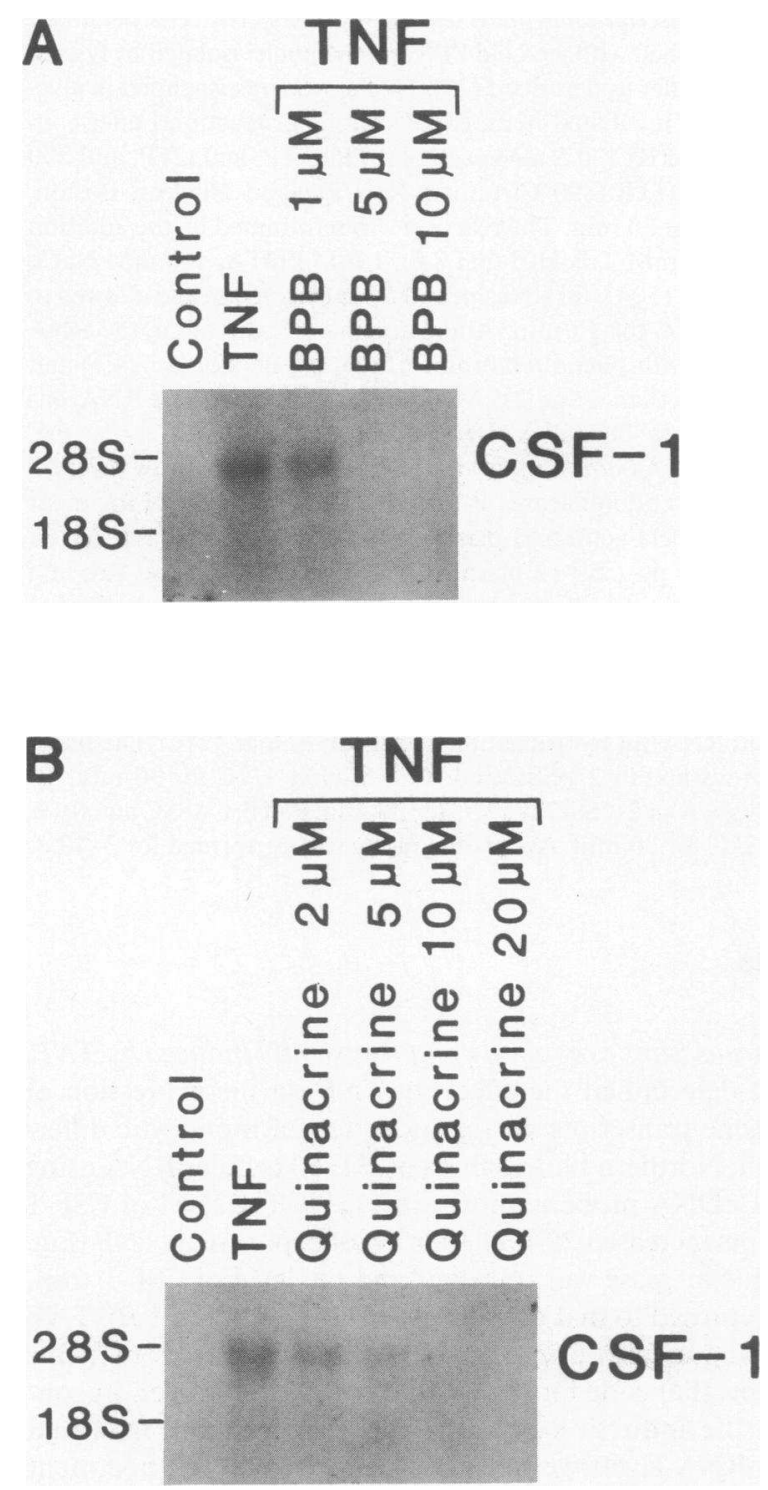

Figure 5. Effects of BPB and quinacrine on CSF-1 gene expression in TNF-treated HL-60 cells. $(A)$ HL-60 cells were treated with TNF $(100 \mathrm{U} / \mathrm{ml})$ for $3 \mathrm{~h}$ in the presence of varying concentrations of BPB and monitored for CSF-1 RNA. $(B)$ Graded doses of quinacrine were added concomitantly with $100 \mathrm{U} / \mathrm{ml}$ TNF for $3 \mathrm{~h}$. Hybridizations were performed with ${ }^{32} \mathrm{P}$-labeled CSF-1 probe. Control indicates RNA from untreated HL-60 cells. 
whereas $10 \mu \mathrm{M}$ quinacrine completely inhibited the effects of TNF on CSF-1 gene expression (Fig. 5 B).

Arachidonic acid is the major substrate for 5-lipoxygenase (5-LO) and cyclooxygenase with formation of leukotrienes and prostaglandins, respectively. Thus, it was also of interest to determine the effects of these metabolites on CSF-1 expression. Leukotriene production is inhibited by the 5-LO pathway inhibitor, caffeic acid (28). Treatment of HL-60 cells with caffeic acid in the presence of TNF had no detectable effect on the induction of CSF-1 RNA (Fig. 6). Similar results were obtained with another 5-LO pathway inhibitor, nordihydroguaiaretic acid (NDGA) (29) (Fig. 6). Furthermore, treatment of $\mathrm{HL}-60$ cells with the 5-LO metabolite leukotriene $\mathrm{B}_{4}\left(\mathrm{LTB}_{4}\right)$ failed to induce CSF-1 transcripts (data not shown).

Previous studies had shown that the cyclooxygenase metabolite $\mathrm{PGE}_{2}$ is a potent regulator of monokine production (30). Thus, we first studied the effects of the cyclooxygenase inhibitor indomethacin (31) on CSF-1 gene expression. Indomethacin alone had no effect on CSF-1 expression, and in combination with TNF had no detectable effect on the induction of CSF-1 RNA (Fig. 7). However, $\mathrm{PGE}_{2}$ treatment of TNF-induced HL-60 cells blocked the expression of CSF-1 RNA in a dose-dependent manner (Fig. $8 \mathrm{~A}$ ). $\mathrm{PGE}_{2}$ decreased the accumulation of CSF- 1 transcripts by 78 and $89 \%$ at concentrations of 1 and $10 \mathrm{nM}$, respectively. Furthermore, treatment of HL-60 cells with $200 \mathrm{U} / \mathrm{ml}$ TNF and $1 \mu \mathrm{M} \mathrm{PGE}_{2}$ inhibited CSF-1 gene transcription by $89 \%$ as compared with cells treated with TNF alone. Since we had previously shown (32) that TNF treatment of HL-60 cells had no significant effect on the production of cAMP and that $\mathrm{PGE}_{2}$ increased cAMP levels in both untreated and TNF-stimulated HL-60 cells, it was also of interest to determine if the effects of $\mathrm{PGE}_{2}$ on CSF-1 transcripts could be mimicked by the addition of exogenous cAMP. Indeed, decreases in the induction of CSF-1 transcripts by TNF were observed in HL-60 cells treated with dibutyryl cAMP (Bt ${ }_{2} \mathrm{cAMP}$ ) (Fig. $8 \mathrm{~B}$ ).

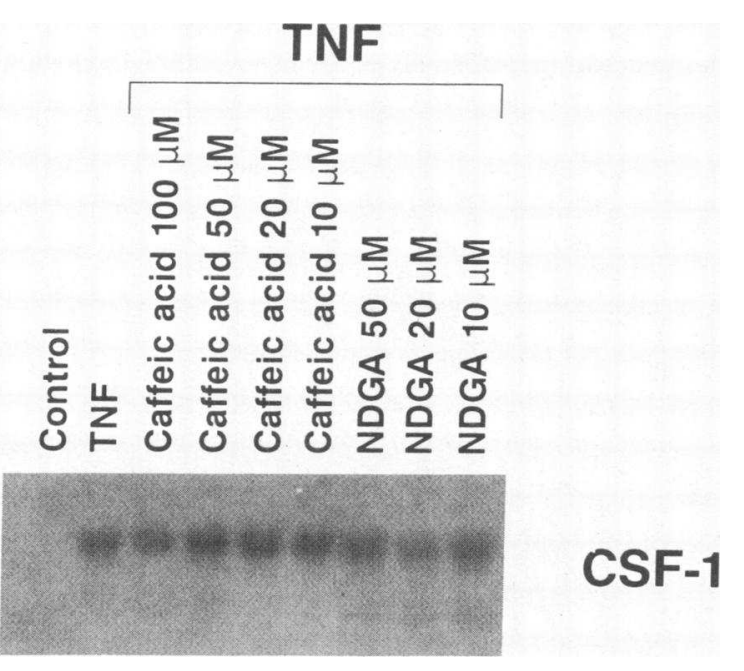

Figure 6. Effects of lipoxygenase inhibitors on the induction of CSF-1 transcripts by TNF. HL-60 cells were treated with TNF (200 $\mathrm{U} / \mathrm{ml}$ ) for $3 \mathrm{~h}$ and in the presence of varying doses of caffeic acid or NDGA. Total cellular RNA $(20 \mu \mathrm{g})$ was isolated for Northern blot analysis. The control lane represents RNA from untreated HL-60 cells.

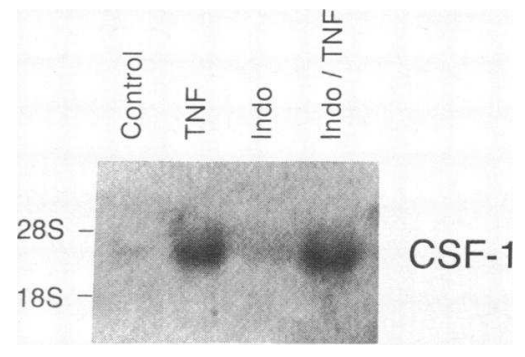

Figure 7. Effects of cyclooxygenase inhibition on the induction of CSF-1 transcripts by TNF. HL-60 cells were treated with TNF $(200$ $\mathrm{U} / \mathrm{ml}$ ) for $3 \mathrm{~h}$ and in the presence of $1 \mu \mathrm{M}$ indomethacin (Indo). Hybridizations were performed with ${ }^{32} \mathrm{P}-\mathrm{la}-$

beled CSF-1 probe. Control indicates RNA from untreated HL-60 cells.

\section{Discussion}

TNF induces HL-60 cells to undergo monocytic differentiation. In this regard, HL-60 cells treated with TNF express histochemical, morphological, and functional characteristics of the monocytic lineage $(17,33)$. The effects of TNF on the regulation of gene expression during HL-60 cell differentiation have been less clearly defined. TNF treatment of HL-60 cells is associated with a down regulation of c-myc gene expression at the transcriptional level $(18,19)$. Recent studies have also demonstrated the autoinduction of TNF gene expression by TNF in HL-60 cells. ${ }^{2}$

The present results indicate that TNF induces transcriptional activation of the CSF-1 gene and appearance of CSF-1 transcripts in HL-60 cells. This induction of CSF-1 transcripts was also associated with expression of the CSF-1 receptor gene. Recent studies have demonstrated that phorbol diesters regulate CSF-1 gene expression by transcriptional and posttranscriptional mechanisms (9). The present findings suggest that similar effects may play a role in the regulation of this gene by TNF. TNF treatment of HL-60 cells was associated with transcriptional activation of the CSF-1 gene. Furthermore, the results indicate that posttranscriptional mechanisms requiring de novo protein synthesis regulate CSF-1 gene expression in TNF-treated cells. In this regard, inhibition of protein synthesis by cycloheximide had no effect on CSF-1 expression in untreated HL-60 cells, but increased levels of CSF-1 transcripts by 3.4-fold during TNF treatment. Furthermore, although cycloheximide had no effect on CSF-1 gene transcription, this agent did prolong the half-life of the CSF-1 transcript. This posttranscriptional regulation of CSF-1 mRNA levels may be related to the presence of several short AU-rich sequences in the $3^{\prime}$ untranslated region of its mRNA (23). These sequences appear to mediate selective processing and degradation of mRNAs for certain other cytokines and protooncogenes $(34,35)$.

The interaction of growth factors with their receptors is associated with the generation of second messengers. Our previous work has shown that autoinduction of TNF gene expression is mediated by phospholipase $A_{2}$ activity and arachidonic acid metabolites. ${ }^{2}$ In this regard, TNF mRNA is induced by the 5-LO metabolite $\mathrm{LTB}_{4}$ in HL-60 cells. The present results demonstrate that induction of CSF-1 transcripts by TNF is also mediated by the arachidonic acid cascade. Inhibition of phospholipase $A_{2}$ activity by BPB or quinacrine blocked TNF-induced expression of CSF-1 RNA. However, in contrast to the autoinduction of TNF mRNA, the present 

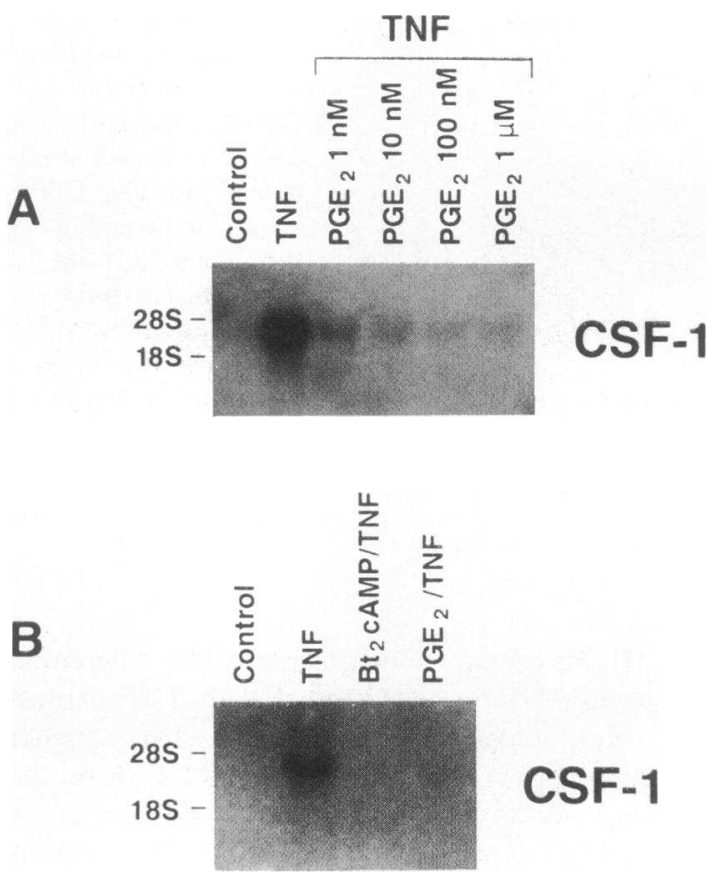

Figure 8. Effects of $\mathrm{PGE}_{2}$ on TNF induction of gene expression. $(A)$ HL-60 cells were treated with TNF $(200 \mathrm{U} / \mathrm{ml})$ for $3 \mathrm{~h}$ alone and in the presence of varying concentrations of $\mathrm{PGE}_{2}$, and monitored for CSF-1 RNA by Northern blot analysis. (B) HL-60 cells were treated with TNF $(200 \mathrm{U} / \mathrm{ml})$ for $3 \mathrm{~h}$ alone and in the presence of $500 \mu \mathrm{M}$ $\mathrm{Bt}_{2} \mathrm{CAMP}$ or $1 \mu \mathrm{M}$ PGE 2 . Total cellular RNA $(20 \mu \mathrm{g})$ was isolated for Northern blot analysis. The control lane represents RNA from untreated HL-60 cells.

studies indicate that inhibition of 5-LO activity with caffeic acid or NDGA had no detectable effect on the induction of CSF-1 transcripts. Furthermore, while the 5-LO metabolite $\mathrm{LTB}_{4}$ induced TNF expression, there was no increase in CSF-1 transcripts detected after treatment of HL-60 cells with this leukotriene. Taken together, these findings would suggest that in contrast to the activation of TNF gene expression, other eicosanoids are probably required for inducing CSF-1 transcripts in these cells. For example, arachidonic acid is also a substrate for the 15-lipoxygenase (15-LO) enzyme with production of lipoxins $A_{4}$ and $B_{4}$. The lipoxins are potent activators of protein kinase $C(36)$ and in view of our findings that phorbol esters induce CSF-1 transcripts (9), these 15-LO metabolites may be involved in the regulation of CSF-1 expression.

$\mathrm{PGE}_{2}$ generated by cyclooxygenase metabolism of arachidonic acid is a potent immunomodulatory agent which mediates cell function by transducing information via the second messenger cAMP. Murine macrophages possess $\mathrm{PGE}_{2}$-specific receptors and prostaglandin-sensitive adenylate cyclase. TNF treatment of resting macrophages or synovial cells releases $\mathrm{PGE}_{2}$ into the supernatant $(37,38)$. Furthermore, $\mathrm{PGE}_{2}$ treatment of murine peritoneal macrophages blocks LPS-induced expression of TNF mRNA (30). Previous studies in a murine osteoblast-like cell line have demonstrated that TNF stimulates production of $\mathrm{PGE}_{2}$ and macrophage-colony stimulating activity (39). However, while indomethacin abolished TNFinduced $\mathrm{PGE}_{2}$ production in these cells, there was little, if any, effect on induction of colony stimulating activity (39).
In the present studies, inhibition of the cyclooxygenase pathway had no effect on induction of CSF-1 mRNA. However, $\mathrm{PGE}_{2}$ was a potent inhibitory signal for the induction of CSF-1 transcripts by TNF. $\mathrm{Bt}_{2} \mathrm{CAMP}$ also inhibited the induction of CSF-1 transcripts. These findings suggested that the effects of $\mathrm{PGE}_{2}$ may be due, at least in part, to cAMP metabolism. Recent results have demonstrated that the induction of TNF mRNA is also inhibited by the cyclooxygenase metabolite $\mathrm{PGE}_{2}$ (40). Thus, although the early events that induce CSF-1 mRNA transcription appear to be distinct from that for the induction of TNF transcripts, cAMP represents a common inhibitory signal for induction of both the CSF-1 and TNF genes.

TNF-induced stimulation of phospholipase $A_{2}$ and production of arachidonic acid is thus associated with induction of several genes involved in monocytic differentiation. Arachidonic acid formation is the rate-limiting step in the synthesis of multiple metabolites including leukotrienes, lipoxins and prostaglandins. This cascade of secondary messengers appears to be involved in the regulation of genes required for the proliferation, differentiation, and activation of monocytes.

\section{Acknowledgments}

This investigation was supported in part by Public Health Service Clinical Investigator Award K08 CA-01092 awarded by the National Cancer Institute, Dept. of Health and Human Services (Dr. M. L. Sherman), and by a Burroughs Wellcome Clinical Pharmacology Scholar Award (Dr. D. W. Kufe).

\section{References}

1. Stanley, E. R., D.-M. Chen, and H.-S. Lin. 1978. Induction of macrophage production and proliferation by a purified colony stimulating factor. Nature (Lond.). 274:168-170.

2. Stanley, E. R., L. J. Guilbert, R. J. Tushinski, and S. H. Bartelmez. 1983. CSF-1: a mononuclear phagocyte lineage-specific hemopoietic growth factor. J. Cell. Biochem. 21:151-159.

3. Kurland, J. I., L. M. Pelus, P. Ralph, R. S. Bockman, and M. A. S. Moore. 1979. Induction of prostaglandin E synthesis in normal and neoplastic macrophages. Role for colony stimulating factor(s) distinct from effects on myeloid progenitor cell proliferation. Proc. Natl. Acad. Sci. USA. 76:2326-2330.

4. Lin, H.-S., and S. Gorden. 1979. Secretion of plasminogen activator by bone marrow-derived mononuclear phagocytes and its enhancement by colony-stimulating factor. J. Exp. Med. 150:231-239.

5. Moore, R. N., J. J. Oppenheim, J. J. Farrar, C. S. Carter, Jr., A. Waheed, and R. K. Shadduck. 1980. Production of lymphocyte activating factors (interleukin 1) by macrophages activated with colony stimulating factors. J. Immunol. 125:1302-1305.

6. Metcalf, D., and N. A. Nicola. 1985. Synthesis by mouse peritoneal macrophages of G-CSF, the differentiation inducer for myeloid cells: stimulation by endotoxin, M-CSF and multi-CSF. Leuk. Res. 9:35-50.

7. Fleit, H. B., and M. Rabinovitch. 1981. Interferon induction in marrow derived macrophages: regulation by $L$ cell conditioned medium. J. Cell. Physiol. 108:347-352.

8. Warren, M. K., and P. Ralph. 1986. Macrophage growth factor CSF-1 stimulates human monocyte production of interferon, tumor necrosis factor, and colony stimulating activity. J. Immunol. 137:2281-2285.

9. Horiguchi, J., E. Sariban, and D. Kufe. 1988. Transcriptional and posttranscriptional regulation of CSF-1 gene expression in human monocytes. Mol. Cell. Biol. 8:3951-3954. 
10. Horiguchi, J., M. K. Warren, and D. Kufe. 1987. Expression of the macrophage-specific colony-stimulating factor in human monocytes treated with granulocyte-macrophage colony-stimulating factor. Blood. 69:1259-1261.

11. Horiguchi, J., M. K. Warren, P. Ralph, and D. Kufe. 1986. Expression of the macrophage-specific colony-stimulating factor (CSF-1) during human monocytic differentiation. Biochem. Biophys. Res. Commun. 141:924-930.

12. Ralph, P., M. K. Warren, M. T. Lee, J. Csejtey, J. F. Weaver, H. E. Broxmeyer, D. E. Williams, E. R. Stanley, and E. S. Kawasaki. 1986. Inducible production of human macrophage growth factor, CSF-1. Blood. 68:633-639.

13. Horiguchi, J., M. L. Sherman, A. Sampson-Johannes, B. L. Weber, and D. W. Kufe. 1988. CSF-1 and c-fms gene expression in human carcinoma cell lines. Biochem. Biophys. Res. Commun. 157:395-401.

14. Broxmeyer, H. E., D. E. Williams, L. Lu, S. Cooper, S. L. Anderson, G. S. Beyer, R. Hoffman, and B. Y. Rubin. 1986. The suppressive influences of human tumor necrosis factors on bone marrow hematopoietic progenitor cells from normal donors and patients with leukemia: synergism of tumor necrosis factor and gamma-interferon. J. Immunol. 136:4487-4495.

15. Murphy, M., B. Perussia, and G. Trinchieri. 1986. Effects of recombinant tumor necrosis factor, lymphotoxin and interferongamma on human bone marrow cells enriched for hematopoietic precursors. Blood. 68(Suppl. 1):173a. (Abstr.)

16. Peetre, C., U. Gullberg, E. Nilsson, and I. Olsson. 1986. Effects of recombinant tumor necrosis factor on proliferation and differentiation of leukemic and normal hematopoietic cells in vitro. J. Clin. Invest. 78:1694-1700.

17. Trinchieri, G., M. Kobayashi, M. Rosen, R. Loudon, M. Murphy, and B. Perussia. 1986. Tumor necrosis factor and lymphotoxin induce human myeloid cell lines in synergy with immune interferon. J. Exp. Med. 164:1206-1225.

18. Tobler, A., D. Johnston, and H. P. Koeffler. 1987. Recombinant human tumor necrosis factor-alpha regulates $\mathrm{c}$-myc expression in HL-60 cells at the level of transcription. Blood. 70:200-205.

19. Kronke, M., C. Schulter, and K. Pfizenmaier. 1987. Tumor necrosis factor inhibits myc expression in HL-60 cells at the level of mRNA transcription. Proc. Natl. Acad. Sci. USA. 84:669-673.

20. Koeffler, H. P., J. Gasson, and A. Tobler. 1988. Transcriptional and posttranscriptional modulation of myeloid colony-stimulating factor expression by tumor necrosis factor and other agents. Mol. Cell. Biol. 8:3432-3438.

21. Oster, W., A. Lindermann, S. Horn, R. Mertelsmann, and F. Herrmann. 1987. Tumor necrosis factor (TNF)-alpha but not TNFbeta induces secretion of colony stimulating factor for macrophages (CSF-1) by human monocytes. Blood. 70:1700-1703.

22. Sariban, E., R. Luebbers, and D. W. Kufe. 1988. Transcriptional and posttranscriptional control of c-fos gene expression in human monocytes. Mol. Cell. Biol. 8:340-346.

23. Kawasaki, E. S., M. B. Ladner, A. M. Wang, J. Van Arsdell, M. K. Warren, M. Y. Coyne, V. L. Schweickart, M.-T. Lee, K. J. Wilson, A. Boosman, E. R. Stanley, P. Ralph, and D. F. Mark. 1985. Molecular cloning of a cDNA encoding human macrophage-specific colony-stimulating factor (CSF-1). Science (Wash. DC). 230:291-296.

24. Coussens, L., C. Van Beveren, D. Smith, E. Chen, R. L. Mitchell, C. M. Isacke, I. M. Merma, and A. Ullrich. 1986. Structural alteration of viral homologue of receptor proto-oncogene fms at carboxyl terminus. Nature (Lond.). 320:277-280.
25. Cleveland, D. W., M. A. Lopata, R. J. MacDonald, N. J. Cowan, W. J. Rutter, and M. W. Kirschner. 1980. Number and evolutionary conservation of alpha- and beta-tubulin and cytoplasmic betaand gamma-actin genes using specific cloned cDNA probes. Cell. 20:95-105.

26. Sakata, A., E. Ida, M. Tominaga, and K. Onoue. 1987. Arachidonic acid acts as an intracellular activator of NADPH-oxidase in Fc receptor-mediated superoxide generation in macrophages. $\mathrm{J}$. Immunol. 138:4353-4359.

27. Tsunawaki, S., and C. Nathan. 1986. Release of arachidonate and reduction of oxygen. J. Biol. Chem. 261:11563-11570.

28. Koshihara, Y., T. Neichi, S.-I. Murota, A.-N. Lao, Y. Fujimoto, and T. Tatsuno. 1984. Caffeic acid is a selective inhibitor for leukotriene biosynthesis. Biochim. Biophys. Acta. 792:92-97.

29. Humes, J. L., S. Sadowski, M. Galavage, M. Goldenberg, E. Subers, F. A. Kuehl, Jr., and R. J. Bonney. 1983. Pharmacological effects of non-steroidal prostaglandin and leukotriene synthesis in mouse peritoneal macrophages. Biochem. Pharmacol. 32:2319-2322.

30. Kunkel, S. L., M. Spengler, M. A. May, R. Spengler, J. Larrick, and $D$. Remick. 1988. Prostaglandin $E_{2}$ regulates macrophage-derived tumor necrosis factor gene expression. J. Biol. Chem. 263:5380-5384.

31. Vane, J. R. 1971. Inhibition of prostaglandin synthesis as a mechanism of action for aspirin-like drugs. Nat. New Biol. 231:232235.

32. Imamura, K., M. L. Sherman, D. Spriggs, and D. Kufe. 1988. Effect of tumor necrosis factor on GTP binding and GTPase activity in HL-60 and L929 cells. J. Biol. Chem. 263:10247-10253.

33. Trinchieri, G., M. Rosen, and B. Perussia. 1987. Induction of differentiation of human myeloid cell lines by tumor necrosis factor in cooperation with $1 \alpha, 25$-dihydroxyvitamin $\mathrm{D}_{3}$. Cancer Res. 47:22362242.

34. Caput, D., B. Beutler, K. Hertog, R. Thayer, S. Brown-Shimmer, and A. Cerami. 1986. Identification of a common nucleotide sequence in the $3^{\prime}$ untranslated region of mRNA molecules specifying inflammatory mediators. Proc. Natl. Acad. Sci. USA. 83:1670-1674.

35. Shaw, G., and R. Kamen. 1986. A conserved AU sequence from the 3' untranslated region of GM-CSF mRNA mediates selective mRNA degradation. Cell. 46:659-667.

36. Hansson, A., C. N. Serhan, J. Haeggstrom, M. IngelmanSundberg, and B. Samuelsson. 1986. Activation of protein kinase $C$ by lipoxin $A$ and other eicosanoids. Intracellular action of oxygenation products of arachidonic acid. Biochem. Biophys. Res. Commun. 134:1215-1222.

37. Bachwich, P. R., S. W. Chensue, J. W. Larrick, and S. L. Kunkel. 1986. Tumor necrosis factor stimulates interleukin-1 and prostaglandin $\mathrm{E}_{2}$ production in resting macrophages. Biochem. Biophys. Res. Commun. 136:94-101.

38. Dayer, J. M., B. Beutler, and A. Cerami. 1985. Cachectin/ tumor necrosis factor stimulates collagenase and prostaglandin $E_{2}$ production by human synovial cells and dermal fibroblasts. J. Exp. Med. 162:2163-2168.

39. Sato, K., K. Kasono, Y. Fujii, M. Kawakami, T. Tsushima, and K. Shizume. 1987. Tumor necrosis factor type alpha (cachectin) stimulates mouse osteoblast-like cells (MC3T3-E1) to produce macrophagecolony stimulating activity and prostaglandin $\mathrm{E}_{2}$. Biochem. Biophys. Res. Commun. 145:323-329.

40. Horiguchi, J., D. Spriggs, K. Imamura, R. Stone, R. Luebbers, and D. Kufe. 1989. Role of arachidonic acid metabolism in transcriptional induction of tumor necrosis factor gene expression by phorbol esters. Mol. Cell. Biol. 9:252-258. 